\title{
ОСТАННІЙ СПЛЕСК У ТВОРЧОСТІ ОЛЕКСІЯ КУНДЗІЧА
}

У статті окреслено фрагмент наукової біографії українського письменника Олексія Кундзіча, яка спирається не лише на його автобіографічні відомості, але й на свідчення сучасників, спогади близьких $i$ рідних, на архівні джерела. У статті йдеться про післявоєнний період творчості О. Кундзіча. Уточнено окремі моменти його творчої біографії. Прокоментовано деякі позииї ії різночитань стосовно післявоєнного періоду життя письменника, щзо дає можливість заповнити лакуни у вивченні життєвого і творчого шляху мития. Подано перспективи щзодо подальших досліджень теми.

Ключові слова : наукова біографія, новела, нарис, оповідання, роман.

Українське літературознавство початку XXI століття рішуче переглядає оцінки i аспекти дослідження художнього процесу радянської доби, переосмислює індивідуальний внесок письменників першої половини XX століття у скарбницю мистецького слова. На часі об'єктивне вивчення творчості примусово вилучених із літературно-критичної рецепції авторів, тому дослідження творчого шляху Олексія Кундзіча, для вітчизняного читача постаті маловідомої, а в гіршому випадку - одіозної завдяки відверто кон'юнктурним творам, $є$ актуальним.

Основною метою статті $\epsilon$ прояснення «білих плям» та дискусійних моментів наукової біографії О. Кундзіча, грунтоване на опрацюванні архівних та маловідомих матеріалів, пов'язаних із життєвим i творчим шляхом письменника.

Практично одразу ж після війни, у 1945 році, О. Кундзіч написав невеличкий нарис «Осінній етюд», у якому передав свій урочистий настрій, «що буває після піднесених засідань в роковини великих подій» $[12,147]$. М. Шумило, коментуючи цей твір, пригадує, як письменник, вийшовши 3 оперного театру, побачив перед собою Київ, відчув душею всю країну. «...Здавалося, я очима бачив, вухами чув цей могутній табір рідного краю. Я почував його в усій розмаїтості його завдань, його прагнень, великих задумів і робіт, і це було почуття країни в часі, ось саме в цій осені, після перемоги, в цьому вечорі, - те почуття, яким визначаєш свої координати на землі і знаходиш своє робоче місце, те почуття народу, що ним ти вимірюєш свій труд і встановлюєш сенс існування...» $[12,148]$. У спогадах М. Шумила йдеться і про те, що О. Кундзіч працював у повоєнні роки над великим «романом про змагання двох світів - соціалістичного і капіталістичного, змагання в творчості, в техніці, в науці» $[12,152]$, однак несподівана хвороба відсунула цей задум на тривалий час (очевидно, йшлося про роман «На світі точиться великий спір»). 
У 1946 році вийшла повість «Як Тарас їхав по Україні», яку Б. Корсунська називає уривком із роману «Тарас Палюта» [4, 138]. Дружина письменника у спогадах пише про незакінчену трилогію «Життя Ярини Мазур» [3, 232], задум якої виник під час війни.

Із поверненням до мирного життя існування сім’ї Кундзічів знову не було легким. У ті роки письменник підробляв у Кабінеті молодого автора і чимало зробив доброго для початківців. Але саме тоді О. Кундзіч знову зазнав нищівних офіційних нападок за опубліковані уривки із задуманого ним роману «Як Тарас їхав по Україні» та оповідання «Українська хата» в газеті «Література і мистецтво» (1943): до письменника повернулося таке знайоме йому амплуа «показового носія усіх гріхів». У розділах незавершеного роману було виразно окреслено постаті овіяного легендами командира партизанського загону Тараса Палюти і його побратима, який стає активним учасником партизанської боротьби. На перший погляд, це не могло містити жодної крамоли, але натреновані критикани-винищувачі вміли читати поміж рядків і «шити справу».

О. Кундзіч згадує, що збірка оповідань «Українська хата» - це твори про життя України у воєнні роки. «Та й iї розкритикували! Зробили 3 мене пропагандиста ідей, ворожих радянському світогляду, звинуватили в націоналізмі, антирадянських настроях, бозна в чім ще...» [10, 7]. Критика була розгромною, шокуючою. Його цькували в пресі, «розбирали» на зборах у Спілці письменників, звинувачуючи в українському буржуазному націоналізмі. Свген Адельгейм закидає О. Кундзічу, що він «...поетизує дезертирство і анархію, паплюжить радянську інтелігенцію і заводить нас у глухі хащі націоналістичних ідей» $[1,3]$. Після цієї «гострої, надто суворої критики» $[12,152]$ письменник пережив чи не найчорніші дні у своєму житті. Друзі пригадують його розгубленим, замкненим у собі. Ці події не могли не позначитися на фізичному та моральному стані Олексія Кундзіча. Він захворів, і недуга затяглася на кілька років.

18 квітня 1945 р. О. Кундзіч іде 3 редакції газети «Література і мистецтво». Того ж дня він написав відчайдушного листа Дмитрові Мануїльському, тодішньому заступнику голови уряду й наркому іноземних справ УРСР: «Останніми днями два критики, Овчаров і Хінкулов, посилено намагаються в літературних кулуарах переконати людей у тому, що в моєму уривкові «Живу» 3 незакінченого роману «Тарас Палюта» - біологізм i контрреволюція. Дослухавшись критиків, письменники знайомляться 3 уривком, дивуються й висловлюють мені співчуття... Помилки бувають i, можливо, вони є і в наших учорашніх творах і слід про них говорити, але говорити на високому рівні розуміння мистецтва, творчо, говорити 3 письменником, а не травмувати його... Ви легко можете уявити його після появи у пресі такого безцеремонного удару - він соромиться зустріти товаришів, його побоюються в редакціях, у нього понуро в родині, в хаті, він на певний період уже не робоча одиниця... Думаючи над книжкою, письменник мріє (взагалі, замисел - це мрія), а чи може мріяти побитий оглоблею Овчарова?.. / Роман про Тараса відклав - мушу годувати сім'ю. 
Цілий день мій дотепер належав редакції (нас дуже мало в редакції). Ніч моя. Пишу статті й оповідання... Сьогодні залишив роботу в редакції - через хворобу й для творчої роботи. Дуже втомився, постійно не досипаючи й часто недоїдаючи, знесилився. Увесь час не дозволяв собі навіть пройтися по повітрю - багато замислів, повільно працюю і мало часу... Звісно, простіше писати бойові епізоди чи вигадувати партизанські пригоди, але я не можу дозволити собі розкоші робити чтиво, бо мрію написати ще два справжні романи, а в мене не так багато часу - кожна осінь і кожна весна може виявитися для мене останньою» $[11,7]$.

У 1946 р. у Києві виходить невелика збірочка О. Кундзіча «Дорога на Крем'янець», яка містила лише три твори: «Ой ти, Галю!», «Дорога на Крем'янець», «Тіні старого бору». Твори були написані під впливом вражень від перебування на війні, стали живими свідченнями про поривання і вчинки людей воєнного лихоліття. Оповідання «Ой ти, Галю!» Кундзіч писав рівно 30 ночей.

Загалом же 1946-й рік ${ }^{1}$ був особливо важким для О. Кундзіча. Гостра критика з'являється і в київській, і в московській пресі: одна за одною виходять нищівні статті Л. Серпиліна «О порочном творчестве писателя О. Кундзича» («Правда Украины». - 1946. - 25 марта), Л. Хінкулова «Хибне коло» («Літературна газета». - 1946. - 29 березня ${ }^{2}$ ), М. Постоловського «Идеализация самобытности» («Литературная газета». - 1946. - 14 сентября), Г. Овчарова «В плену национальной ограничености (Письмо с Украины)» («Литературная газета». - 1946. - 5 ноября), про його твори швидко дають «на замовлення» негативні відгуки i О. Корнійчук, Є. Адельгейм, Ю. Кобилецький, Л. Санов (Ю. Кобилецький подав жорстку рецензію до журналу «Дніпро» - 1947, № 7; О. Корнійчук «розніс» публікацію у співдоповіді на ХІ Пленумі СРП СРСР - Літературна газета», 1947, 10 липня; Л. Санов наслідував своїх попередників у промові на Пленумі СРПУ «Літературна газета», 1947, 2 жовтня). Наприклад, С. Адельгейм запопадливо прислужувався перед владою i закидав письменникові поетизацію дезертирства, анархії, паплюження радянської інтелігенції і свідоме заведення читача «у глухі хащі націоналістичних ідей» $[1,3]$. Про цей сумний період у своєму житті О. Кундзіч згадує: «Та особливо суворої критики я зазнав на початку сорок шостого року. Яких тільки «ізмів» не навішували! Та хіба ж тільки мені тоді дісталося? Любов до рідної землі була 3 погляду Лазаря Кагановича найбільшим злочином. Мене ще не так круто зачепило це люте свавілля, а ось Тичину, Рильського, Яновського, Сосюру що вже й казати...» $[10,7]$. До речі, Ю. Мартич писав, що Яновський і

\footnotetext{
1 Згадаймо, щуо у масштабах тодішнього Союзу иче був час, коли приймалися страшні вироки-постанови про журнали «Звезда» $i$ «Ленинград», відлунням яких стали напади на більшість українських журналів.

${ }^{2}$ Прискіпливе гортання иьвого числа газети доводить, щзо нищівні випади проти Кундзіча не обмежилися розлогою статтею Хінкулова: на першій сторінці ще подибуємо й передовиџю «На рівень вимог народу», на наступній - резолючію загальних зборів письменників м. Києва, де різко розкритиковані твори Кундзіча.
} 
Кундзіч не так часто, але зустрічалися і виявляли взаємну глибоку повагу, уважно стежили за творчими планами і літературними здобутками один одного [8, 358].

У 1947 році до всіх звинувачень долучилось стійке таврування в націоналізмі. У родині письменника зберігалась рукописна чернетка листа ${ }^{3}$, надісланого комусь із вищого керівництва УРСР ${ }^{4},-$ свідчення тогочасного душевного сум'яття Кундзіча. «...Цей лист не заява, - це повість, тому що тут душа людини, доля однієї робочої одиниці... Скільки шуму організували навколо сцени з мого уривка, де Тарас радіє, врятувавшись од німців: «Живу! Живу, сто чортів вашій матері» й забуває засипати те місце, де він лежав, засипаний разом з розстріляними. Цілий рік уже мене ганьблять перед усім народом підказаною Хінкуловим формулою «звірячі інстинкти», хоч цей же Тарас увесь сенс життя й порятунку свого убачає в меті - звільнити решту товаришів із табору» [13].

Родина всіляко підтримувала Олексія Леонардовича, проте він почувався ніяково перед дружиною, тому з гіркотою писав у тому ж листі про сімейні очікування тих років: «Дружину я завжди намагаюсь заспокоїти, мені шкода iii, вона зазнала в житті зі мною чимало гірких хвилин. - Усе буде добре, кажу їй щоразу після мимовільної паузи, в якій ми обидва думаємо про те, як усе погано в мене, в нас. I вона намагається підтримати мене морально: Безумовно, все буде добре. - Але я чую, як вона зітхає в іншій кімнаті, з якою тривогою щоразу приймаючи газети, вона шарудить ними, ще в передпокої відшукуючи статті й абзаци, де мене знищують. Кожного разу я кличу іiі: Ходи сюди! Дай мені газети. Що сьогодні? - Вона заспокоює мене: - Нічого. Тільки ім'я. В ряду імен... цих... націоналістів... / Щодня, за рідкісним винятком, протягом півтора року мене всенародно називають націоналістом... Уже півтора року, майже щодня, мене б'ють по тімені - не цитатами 3 моїх творів, не доказами, а готовими голими формулами, створеними під шумок, зловтішно і з розрахунком на те, що ніхто не вступить в захист, не спинить, не закличе до порядку... Кундзіча можна знищити безперешкодно - ця людина не захиститься, не грюкне кулаком по столу, не піде у найвищі інстанції, а якщо піде, то не зуміє викласти суть, хвилюючись і розгубившись. Знає ці мої якості й дружина, i, перебираючи газети, шукаючи моє ім'я, побоюється, як я реагуватиму на сьогоднішні удари» $[11,7]$.

Звинувачення в «націоналізмі» виявилось не єдиним тавром, приписуваним письменникові. «На нього вішали всі «ізми», - згадує дружина. - Коли була кампанія проти космополітизму, то Кундзіч був космополіт, коли проти націоналізму, то - націоналіст, коли проти антисемітизму - то навіть антисемітизм йому приписували» [2, 4], хоч він, як

\footnotetext{
${ }^{3}$ Очевидно, письменник усвідомлював, щуо колись буде переглянуто весь літературний прочес XX cm. і правдиво сказано про партійне втручання в літературу: адже на теці,

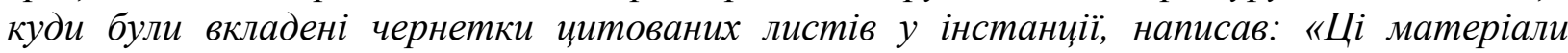
зберегти» $[11,7]$.

${ }^{4}$ У рукописній чернетці ім'я, по батькові і прізвище адресата не зазначено, відповідно, встановити, до кого саме звертався Кундзіч, дуже важко.
} 
i більшість українських письменників, належав до тих, хто активно пропагував здобутки різних національних культур; згадаймо також, що вірним приятелем О. Кундзіча впродовж життя був відомий єврейський поет Матвій Талалаєвський.

Трагедію О. Кундзіча дуже вдало схарактеризував Г. Костюк: «Він був письменником глибоко органічним, тобто письменником такого психологічного й емоційного складу, що міг творити справжні мистецькі речі тільки тоді, коли ідеї та образи природно формувалися в його душі. Він органічно не міг давати повноцінних творів на замовлення... Він цілковито тратив голос або тягнув фальцетом, коли пісню йому хтось замовляв або наказував співати...» [5, 349].

Автор літературно-критичного нарису про О. Кундзіча Берта Корсунська по-іншому підійшла до оцінки «крамольних» творів, зводячи критику лише до закидів у нібито ідеалізації минулого, ідейній невиразності й суперечностях. Але водночас Б. Корсунська, пишучи про оповідання «Українська хата», прихильно відзначає i його позитивні сторони: «...Основою ж твору стає піднятий на рівень філософського узагальнення образ української хати, у якій бачить письменник оплот національних традицій, джерело народного життя, символ душевного здоров'я, мудрості і краси народу, незборності його духу» [ 4, 152].

Тепер літературознавці ці «крамольні писання» визнають чи не найкращими в усьому доробку письменника. У статті, опублікованій 1991 року, В. Поліщук наголошує, що «...за всіма параметрами повість О. Кундзіча «Як Тарас їхав по Україні» $є$ твором визначним, надто для української літератури 40-х років. I в сучасній повістевій прозі про війну вона б не загубилася, ставши поряд із кращими зразками цієї тематики - повістями А. Дімарова, Б. Харчука, Є. Гуцала...» [9, 52].

Але повернімося до кінця 1940-х рр. Критика 1946-1947 рр. була вбивчою: О. Кундзіча, О. Довженка, Ю. Яновського, М. Рильського та інших було звинувачено в «патріархальщині», «рекреаційності», i, найгірше, - «в українському буржуазному націоналізмі», що позначилося на творчій стагнації цілої плеяди тодішнього красного письменства.

Постійні ідеологічні переслідування тяжко відбилися на психологічному стані О. Кундзіча, призвели до нових нервових потрясінь, морального пригноблення. У травні 1946 року О. Кундзіч їде до Ужгорода поправляти здоров'я. 3 листа до сина нам відомо, що мав на меті написати сценарій: «Сценарій - це трудна річ, бо тут маса такого, що треба було б показати, а на кожну таку темку можна окремий (твір) написати. Не знаю, як я виборсаюсь 3 матеріалу. Бо є такий, що його треба, а з екрана буде нецікаво, та й взагалі дуже трудно і клопітно...» [7, 114]. На жаль, ідея сценарію не була зреалізована і залишилася тільки задумом.

Єдиною можливістю «реабілітації» для О. Кундзіча вкотре вбачалась увага до «соціального замовлення». Усвідомлюючи власну відповідальність насамперед перед родиною, він намагається у черговий раз продемонструвати неабияку лояльність до влади i знову їде за свіжими 
враженнями для «обов’язкових» оповідань і «замовного» роману. У 1947 році у листі з Краматорська до сина письменник напише: «Я не хворію, але не можу сказати, що ці митарства по Донбасу легкі для мене. Нелегкі з усіх боків. Темою захоплений, треба буде дуже багато попрацювати над виясненням усього матеріалу. Це треба і внутрішньої сили і фізичної, бо сама територія заводу - кілометри, це ціле місто... По суті, для цього роману на заводі треба було б пожити з рік, а може, й кілька років...» [7, 115]. Після знайомства 3 Краматорськом 3'являються нариси «Начальник цеху», «Українська магнітка», «По діалектиці», «Переможці», «Творчість», «Запорожці», «Південна магнітка», «Шум часу». Їх згодом було вміщено в книзі «Заводський зошит». Збірка була написана не за покликанням, а «на потребу», як данина часові i перепустка у подальше літературне життя, відповідно, тогочасна критика зустріла іiі дуже схвально, про що свідчить стаття С. Жураховича «Заводський зошит» Олексія Кундзіча («Літературна газета». - 1948. - 19 серпня). Чи не тоді він зробив не позначений датою запис у блокноті, яким засвідчив принизливий статус «радянського письменника» середини ХХ століття!? «...Часто досить письменникові взяти дійсний подвиг героя i так-сяк, без любові до вітчизняного мистецтва, примітивно, по-ремісницькому описати його, щоб заробити захоплені відгуки критики. Наче письменник той якось причетний до акту героїзму, погано описаного ним. Тобто йому привласнюють славу героя... Патріотизм митця вбачають не в ділах рук його, не в образах, створених ним на збагачення духовних скарбів Вітчизни, які слугували б народові і в цілому людству..., а в повторюваннях (часто - без приводу) заяв поета про його любов до рідного краю, у віршованих клятвах і деклараціях...» [6, 95-96].

Проте після цього О. Кундзіч практично замовк як прозаїк. За словами В. Поліщука, «хоч задуми нових творів були, та й над удосконаленням попередніх працювалось, але далі з-під пера Кундзіча виходили тільки книги майстерних перекладів i талановиті розвідки 3 теорії перекладацької діяльності» $[9,54]$.

Отже, уточнення наукової біографії Олексія Кундзіча $\epsilon$ актуальним питанням, адже свідчення його друзів містять чимало цікавих даних, що дають можливість заповнити невідомі лакуни у вивченні життєвого i творчого шляху митця. Як бачимо, прояснення «білих плям» та дискусійних моментів наукової біографії письменника дають можливість по-новому побачити потужній творчий сплеск і остаточну зневіру у творчості митця.

ЛІТЕРАТУРА

1. Адельгейм Є. У вузьких берегах / Є. Адельгейм // Літ. газ. - 1946. 12 верес. - С. 3.

2. Бортняк А. На нього вішали всі «ізми» : сьогодні минає 95 років від дня народження Олексія Кундзіча / А. Бортняк // Вінниц. газ. - 1999. 22 квіт. - С. 4.

3. Городецька-Кундзіч К. Людина вмирає до схід сонця... / К. ГородецькаКундзіч // Живий Олексій Кундзіч : записи в щоденнику, листи, спогади про письменника / упоряд. К. А. Городецька-Кундзіч, Б. Л. Корсунська. - К. : 
Рад. письм., 1977. - С. 225-234.

4. Корсунська Б. Л. Олексій Кундзіч : літ.-критич. нарис / Б. Л. Корсунська . - К.: Рад. письм., 1971. - 208 с.

5. Костюк Г. Зустрічі і прощання: спогади : у 2 кн./ Г. Костюк. - Кн.1. Едмонтон, 1987. - С. 75-76, 248, 252-253, 288, 338-351, 355, 479, 515, 678.

6. Кундзіч О. 3 блокнота письменника / О. Кундзіч // Живий Олексій Кундзіч: записи в щоденнику, листи, спогади про письменника / упоряд. К. А. Городецька-Кундзіч, Б. Л. Корсунська. - К., 1977.- С. 93-99.

7. Кундзіч О. 3 листів / О. Кундзіч // Живий Олексій Кундзіч: записи в щоденнику, листи, спогади про письменника / упоряд. К. А. ГородецькаКундзіч, Б. Л. Корсунська. - К., 1977. - С. 104-142

8. Мартич Ю. Перечитуючи книги друзів // Мартич Ю. Зустрічі без прощань бібліограф. розповіді. - К. : Дніпро, 1970. - С. 349-359.

9. Поліщук В. «Наше діло - ламати межі» : про «крамольні твори» Олексія Кундзіча / В. Поліщук // Сл. і час. - 1991. - № 11. - С. 48-54.

10. Савенко I. «...мене не вистачило, щоб реалізувати себе у творчості» : зі спогадів про Олексу Кундзіча / I. Савенко // Літ. Україна. -1997.-20 лист. C.7.

11. Цалик С. «Кундзіча можна знищити безперешкодно...»/ С. Цалик, П. Селігей // Літ. Україна. - 2004. - 29 квіт. - С. 7.

12. Шумило М. 3 глибокого джерела / М. Шумило // Живий Олексій Кундзіч: записи в щоденнику, листи, спогади про письменника / упоряд. К. А. Городецька-Кундзіч, Б. Л. Корсунська. - К., 1977. - С. 147-154.

13. Щоденник, 19.II 1956 / [О. Кундзіч] // Корсунська Б. Л. Олексій Кундзіч : літ.-критич. нарис .- К., 1971. - С. 5.

Статья посвящена раскрытию темы жизни и творчества украинского писателя Алексея Кундзича в годы в период после II Мировой войныл. Автор, ссылаясь на документы, по-новому освещзает и аргументировано комментирует отдельные моменты жсизни Алексея Кундзича. Дано перспективы относительно дальнейтих исследований темьл.

Ключевые слова : научная биография, новелла, очерк, повествование, роман.

The article outlines a piece of the vitae of the Ukrainian writer Oleksiy Kundzich, which is based not only on his autobiographical data, but also on the testimony of contemporaries, memories of friends and relatives, archive sources. The article goes mostly about the post-war period of $O$. Kundzich's career. Some parts of his writing career are clarified and some ways of ambiguity concerning the post-war period of the writer's life, are commented on. This gives an opportunity to fill in blank spots in the writers' personal life and his works. The prospects for further research topics are given.

Key words: vitae, short story, essay, story, novel. 